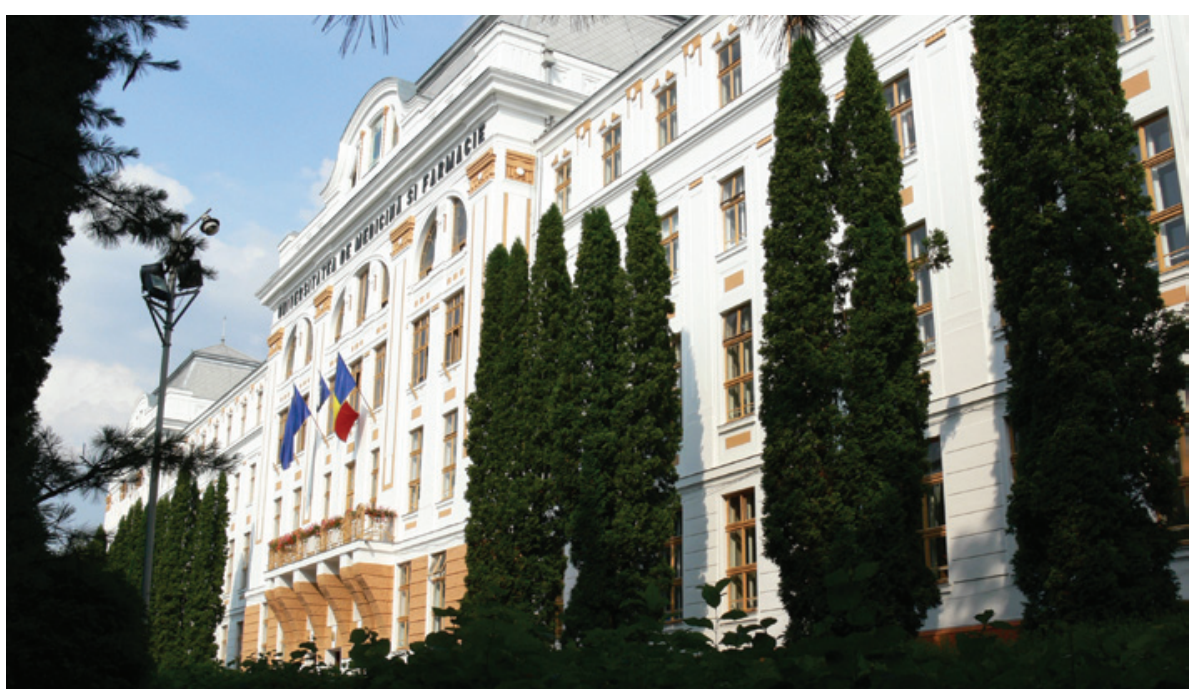

The university at Târgu-Mureş is at the centre of plagiarism accusations.

MISCONDUCT

\title{
Romanian scientists fight plagiarism
}

\section{Researchers set up independent review panel after misconduct scandals hit government.}

\section{BY ALISON ABBOTT}

$\mathrm{P}$ lagiarism scandals have shaken Romania this year. Former research minister Ioan Mang ${ }^{1}$ and current Prime Minister Victor Ponta ${ }^{2}$ have both been implicated, and leaders at a large medical university in Târgu-Mureş face similar accusations although the government seems to have ignored those charges. Such scandals have convinced some Romanian scientists that they need to fight back against a culture of plagiarism that they see as ingrained in the university system.

This week, researchers are launching an online service called Integru, which will investigate and expose cases of plagiarism and other academic misconduct in Romania. Each case will be accompanied online by commentaries from international - and independent - reviewers selected for their expertise in the relevant field.

Integru's stated goal is to "help reform and restore confidence in the Romanian research and education system". Its editorial board, which comprises Romanian scientists working inside and outside the country, will remain anonymous to avoid personal attacks from those accused of misconduct.

Some Romanian academics facing allegations of plagiarism "have tried to dodge the bullet by questioning the motivation of the accusers", says one Integru board member. For example, both Mang and Ponta have belittled the charges against them by arguing that the whistle-blowers were politically motivated. Integru should be able to thwart that strategy, says the board member, "because suspicious papers will be posted alongside documentation of plagiarized and copy-pasted sections, and commented on by credible named experts from credible academic institutes around the world - the misconduct will be hard to refute".

Scientists concerned about plagiarism had once pinned their hopes on Romania's National Ethics Council, which last year was given a strengthened mandate to investigate wrongdoing under a law aiming to raise standards in universities. The council published decisions on 15 cases, and reached conclusions on another three. But many lost faith in its fairness when Ponta's government dismissed all the council's members on 8 June, just as they were poised to vote on the plagiarism charge against Mang (who had already resigned his ministerial post). The council was reconstituted with new members appointed by the government, and its first act was to clear Ponta of his plagiarism charges in July. However, an ethics commission established by the University of Bucharest, which had awarded Ponta his $\mathrm{PhD}$, contradicted that verdict, saying that the prime minister was guilty as charged ${ }^{3}$.

On the day it was dissolved, the former research-ethics council submitted to the science ministry its report on charges of plagiarism against three leading figures at the University of Medicine and Pharmacy of Târgu-Mureş: rector Leonard Azamfirei; former rector Constantin Copotoiu, who is now president of the university senate; and senate member Klara Brânzaniuc, a former vice-rector for research. The ministry has not published the report and did not respond to Nature's request for information about it.

Marius Echim, a physicist at the Belgian Institute for Space Aeronomy in Brussels and vice-president of the dissolved council, chaired the investigation. He says that it "identified clear plagiarism in all three cases and recommended that two of the three professors involved be dismissed from the university". No action has been taken, and the apparent suppression of the case is disturbing, he says. While Echim was on the council, he adds, it saw cases of extensive plagiarism across many different disciplines in Romania.

The Târgu-Mureş cases refer to papers in the university's English-language journal Acta Medica Marisiensis, which contain sections identical to other researchers' works. StefanVirgil Hobai, a biochemist who last year retired from the university, e-mailed university faculty members in December 2011 with evidence of

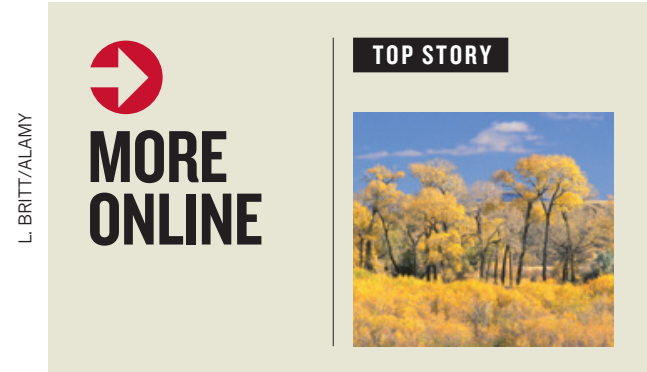

A tree's leaves are genetically different from its roots go.nature.com/ gyq9rf

\section{MORE NEWS}

- Shark-tooth weapons reveal lost biodiversity go.nature.com/acxgoc - Quantum teleportation achieved over record distances go.nature. com/9b2io 4

- Seizure detector treats epilepsy in rats go.nature.com/vhyqof

\section{FROM THE BLOG}

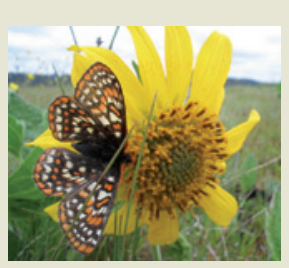

Prisoners pitch in to help save endangered butterfly go.nature. com/4mmckf 
the plagiarism, which Nature has seen. Since then, he has identified a total of 22 cases of apparent plagiarism in Acta Medica Marisiensis and 14 cases in another of the university's journals, the English-language Romanian Review of Laboratory Medicine. That represents $7 \%$ of the papers he examined in each journal.

Peter Hantz, a Romanian physicist of Hungarian ethnicity based at the Friedrich Miescher Institute in Basel, Switzerland, submitted the Copotoiu, Azamfirei and Brânzaniuc cases to the National Ethics Council in January. Azamfirei told Nature that he thought Hantz, a prominent campaigner for Hungarian-language teaching in Romania, may have been trying to discredit the ethnic Romanian university leaders. Târgu-Mureş has a large Hungarian population and a history of ethnic tensions.

Sanda-Maria Copotoiu, editor-in-chief of Acta Medica Marisiensis (and the wife of Constantin Copotoiu), responded to the allegations by publishing an 'expression of concern' in the latest issue of the journal, referring anonymously to Hobai as a "character who styled himself as a prominent researcher and voluntary justice maker", whose "vicious" allegations are "intoxicating the net". She told Nature that all three accused researchers had asked her to remove their names from the papers long before the plagiarism charges reached the ethics council, because they became aware of the papers' existence only after publication. Their names have not yet been withdrawn, but Constantin Copotoiu's paper has been removed from the journal's website.

Constantin Copotoiu and Brânzaniuc did not respond to Nature's request for comment. Azamfirei told Nature that there is no plagiarism in the article with his name on it, and that the National Ethics Council was not the appropriate body to review his case because he was not rector at the time the article was published.

Integru asked three reviewers to take a closer look at the Copotoiu case, and all concluded that the article did contain sections of copied text. One of the reviewers, Mihai Ionac, a vascular surgeon at the Victor Babes University of Medicine and Pharmacy in Timisoara, Romania, says that too many researchers in Romania do not take plagiarism seriously, and may not understand why it is classed as misconduct. The Integru initiative is "extraordinary, and comes at the right time, with all the scandals and turmoil now going on", he says. "Just a few years ago, no-one was even talking about plagiarism - it was covered up, like a cat covers up its dirt." - SEE EDITORIAL P.253

1. Abbott, A. Nature 485, 289 (2012).

2. Schiermeier, Q. Nature 486, 305 (2012).

3. Schiermeier, Q. Nature http://dx.doi. org/10.1038/nature.2012.11047 (2012).

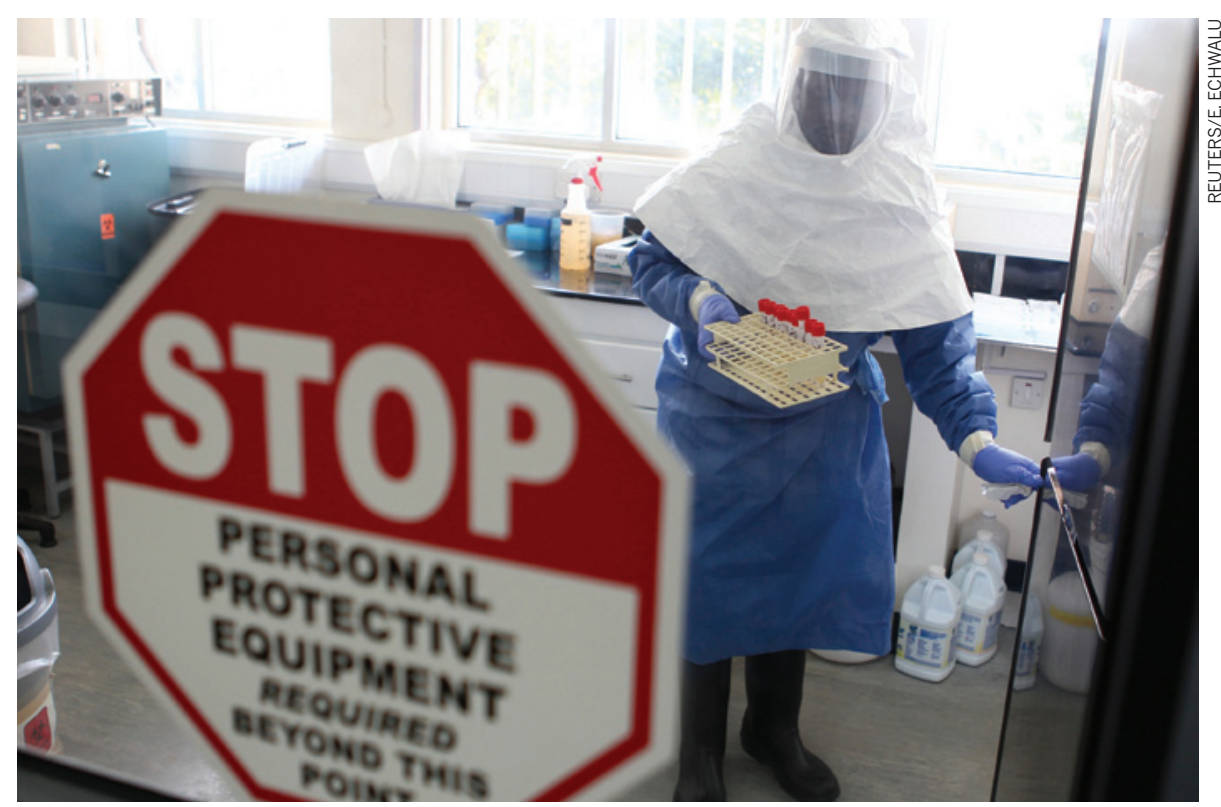

Workers at a biosafety-level-3 lab in Entebbe diagnosed recent cases of Ebola.

INFECTIOUS DISEASES

\section{Ebola outbreak tests local surveillance}

\section{Ugandan laboratory helps to minimize number of cases.}

\section{BY EWEN CALLAWAY}

$\mathrm{F}$ ilm-goers know the script: a frightening infectious disease emerges somewhere in the developing world. Masked healthcare workers arrive, blood samples are rushed to an airfield and the grim diagnosis is finally made in a state-of-the art laboratory on a different continent. But the response to the Ebola infections that have killed at least 16 people in Uganda since early July departed from the script - a laboratory in Entebbe, near Uganda's capital Kampala, has passed its first major test after taking a leading role in confirming and tracking the infection.

The lab, run by the US Centers for Disease Control and Prevention (CDC) and based at the Uganda Virus Research Institute (UVRI), tests tissue samples from patients with symptoms of the viral haemorrhagic fever. Its proximity to the outbreak (see 'Local hero') has helped to speed up the response, and the outbreak now seems to be under control. The episode highlights the advantages of having sophisticated surveillance labs in parts of the world where infections are likely to emerge, says Eddie Holmes, a geneticist who studies emerging infections at Pennsylvania State University in University Park. "The CDC making a commitment to this lab is a tremendous step forward."
The laboratory was set up after a 2007 outbreak of a newly discovered strain of Ebola called Bundibugyo, which killed 42 people. The area hit by the outbreak had no electricity and lacked the facilities to house a mobile containment lab, so scientists studying the disease set up shop at the UVRI. After the Bundibugyo outbreak subsided in 2008, the CDC invested in a permanent laboratory there that could diagnose haemorrhagic fevers such as Ebola and Marburg. Its biosafety-level-3 laboratory is safe enough to diagnose these viruses from tissue samples, but not to grow virus-infected cells for more sophisticated analyses, such as genome sequencing to study virus evolution. For that, samples are still sent to the CDC's headquarters in Atlanta, Georgia.

When the Entebbe lab isn't in outbreak mode - samples still arrive daily from the country's midwestern Kibale district - it can provide negative diagnoses for diseases with symptoms similar to those of viral haemorrhagic fever, such as bloody diarrhoea caused by shigellosis.

Uganda has had three Ebola outbreaks since 2000, so the lab should also help to catch future outbreaks early. "The earlier you catch an epidemic happening, the better you can stop its spread," explains Joseph Fair, vice-president of Metabiota, a company based in San 